Tohoku J. Exp. Med., 2005, 205, 171-178

\title{
Granule Cell Apoptosis Induced by Overdose Copper and Ethanol Is Counterbalanced by Co-Induced Cellular Proliferation in Rat Dentate Gyrus
}

\author{
Ilgaz Akdogan, Esat Adiguzel, Gunfer Turgut, ${ }^{1}$ Osman Genc ${ }^{1}$ and A. Cevik \\ TUFAN $^{2}$ \\ Department of Anatomy, ${ }^{1}$ Department of Physiology, and ${ }^{2}$ Department of \\ Histology and Embryology, School of Medicine, Pamukkale University, Denizli, \\ Turkey
}

Akdogan, I., Adiguzel, E., Turgut, G., Genc, O. and Tufan, A.C. Granule Cell Apoptosis Induced by Overdose Copper and Ethanol Is Counterbalanced by Co-Induced Cellular Proliferation in Rat Dentate Gyrus. Tohoku J. Exp. Med., 2005, 205 (2), 171-178

- Copper $(\mathrm{Cu})$ is an essential element for life, however, is toxic at excessive doses, whereas exposure to ethanol (EtOH) has been known to cause morphological changes, degeneration and neuronal loss in central nervous system (CNS). In this study, the effect of overdose co-exposure to $\mathrm{Cu}$ and $\mathrm{EtOH}$ on dentate gyrus was investigated in rats. Analysis of apoptotic cell death on the basis of TdT-mediated dUTP nick end labeling (TUNEL) assay revealed that the rate of apoptosis was increased by 1.84 folds in treated group in comparison to that in controls $(p<0.0001)$. Analysis of cell proliferation on the basis of 5-bromo-2'-deoxy-uridine labeling assay, on the other hand, revealed a 1.49 fold increase in treated group when compared to controls $(p<0.006)$. Total number of granule cells in dentate gyrus of each group was estimated using the optical fractionator method. The results showed that mean granule cell number in dentate gyrus was $4.64 \%$ lower in treated group than that in control group, but this difference was not statistically significant $(p>$ 0.05). These results suggest that the apoptotic effect of overdose $\mathrm{Cu}$ and $\mathrm{EtOH}$ on granule cells of dentate gyrus may be counterbalanced by the co-induced cellular proliferation, thereby maintaining the total granule cell number unaltered. - copper; ethanol; dentate gyrus; apoptosis; cell proliferation

(C) 2005 Tohoku University Medical Press

As an essential element for life $\mathrm{Cu}$ is toxic at excessive doses (Sarkar 2000). Menkes disease, Wilson's disease, and Alzheimer's disease are among the neurodegenerative central nervous system (CNS) diseases, at which improper $\mathrm{Cu}$ metabolism is implicated in the responsible mechanism of action (Waggoner et al. 1999; Sarkar
2000; Armstrong et al. 2001). Zinc together with $\mathrm{Cu}$ can be neurotoxic at even physiologically relevant concentrations (Horning et al. 2000). Dosedependant neuronal death caused by intrahippocampal $\mathrm{Cu}$ sulphate injection in rats has also been shown (Armstrong et al. 2001). Due to the environmental pollution, people may be exposed to

Received June 10, 2004; revision accepted for publication December 16, 2004.

Address for reprints: Dr.Ilgaz Akdogan, Pamukkale University, Tip Fak, Anatomi AbD, Morfoloji Binası 20020 Kinikli, Denizli, Turkey

e-mail: iakdogan@pamukkale.edu.tr 
high levels of $\mathrm{Cu}$ without recognition (Shallari et al. 1998; Barranguet et al. 2002).

Alcohol, on the other hand, is the most abundantly abused substance worldwide. Exposure to EtOH has been known to cause morphological changes, degeneration and neuronal loss in specific parts of the CNS (Paula-Barbosa et al. 1991; Lukoyanov et al. 2000). Studies with rats have shown that alcohol causes neuronal loss in cerebellum (Chen et al. 2001), basal forebrain (Arendt et al. 1988), hippocampal formation (PaulaBarbosa et al. 1993) and neocortex (Cadete-Leite et al. 1990). Excessive EtOH consumption may lead to cognitive dysfunction (Charness 1993; Lukoyanov et al. 2000). Behavioral changes after chronic alcohol consumption have shown to be due to the neurodegeneration in cholinergic nuclei of the hippocampal formation and basal forebrain, central nervous system areas implicated in learning and memory (Lukoyanov et al. 2000). Furthermore, short-term (4 days) binge exposure to $\mathrm{EtOH}$ causes neuronal death in hippocampal formation (Obernier et al. 2002). In addition, hippocampal formation has been shown to be one of the most vulnerable areas to alcohol effects (Paula-Barbosa et al. 1991). The toxic effect of chronic alcohol exposure on hippocampus in human has also been shown (Bengochea and Gonzalo 1990).

The major cell population of the dentate gyrus, a structure of the hippocampal formation, is composed of granule cells (Berry et al. 1995). Dentate gyrus has afferent and efferent connections to the brain areas implicated in learning and memory (Amaral and Witter 1989; Berry et al. 1995). The three-layered structure of dentate gyrus is similar to that of hippocampus (Berry et al. 1995). We have previously shown that exposure to copper together with $\mathrm{EtOH}$ causes neuronal loss in rat hippocampus (Turgut et al. 2003). However, a recent study by Zharkovsky et al. (2003) showed that production of the new cells accompanied the neurodegeneration in the dentate gyrus of rats after a single high dose administration of EtOH alone. Thus, the objective of this study was to expose the granule cells of the dentate gyrus to a proven potent neurodegenerative treatment, i.e., overdose $\mathrm{Cu}$ and EtOH co-treatment over a period of 10 days, in order to test the regeneration ability of this gray matter tissue under more potent and extended neurodegenerative treatment conditions in rats.

\section{Materials and Methods}

Total 24 Wistar adult rats (15 weeks of age) obtained from Pamukkale University Experimental Animal Facility (Denizli, Turkey) were randomly allocated to two groups: a treated group $(n=12)$ and a control group $(n=12)$. This study was approved by the Pamukkale University Medical Ethics Committee. The animals were maintained under standard laboratory conditions (temperature $22^{\circ} \mathrm{C}$; light/dark cycle $12 / 12$ hours; ad libitum availability of pellet food). Animal care and all experimental procedures used were in accordance with those detailed in the Guide for Care and Use of Laboratory Animals published by the US Department of Health and Human Services. Treated group was given EtOH 20\% $(0.5 \mathrm{ml})$ with $\mathrm{Cu}$ sulphate $(100 \mathrm{mg})$ in $25 \mathrm{ml}$ drinking water every day for 10 days. Control animals were given drinking water only. At the end of 10 days animals were anaesthetized with light ether and decapitated. Brains were removed by craniotomy. Six randomly selected whole brains from each group were halved and one half of each pair was processed for TUNEL assay while the other half was processed for BrdU labeling as described below. The remaining 6 whole brains from each group were frozen in a cryostat (Leica CM3050, Bensheim, Germany) at $-50^{\circ} \mathrm{C}$.

Assessment of the apoptosis on the basis of TUNEL assay

Six half brains from each group were fixed in formaldehyde $(10 \%)$ and processed for routine paraffin embedding. Paraffin-embedded sections of $10 \mu \mathrm{m}$ were cut throughout the tissue and 5-10 sections chosen according to systematic random sampling scheme from each sample were processed with In Situ Cell Death Detection Kit, AP (Roche, Penzberg, Germany) according to the manufacturers protocol for paraffin-embedded tissues. BM Purple AP Substrate, precipitating (Roche, Penzberg, Germany) chromogenic substrate was used for alkaline phosphatase enzyme immunoassay at the last step. Labeled granule cells of dentate gyrus from 4 individual arbitrary unit areas chosen according to systematic random sampling scheme from each section were counted. A consecutive section of each labeled section was stained with hematoxylen and eosin for the maintenance of ori- 
entation.

Assessment of the granule cell proliferation on the basis of BrdU labeling assay

Six half brains from each group were sliced (1-2 $\mathrm{mm}$ thin), BrdU labeled, fixed (in $10 \%$ formaldehyde) and processed for routine paraffin embedding according to the protocol described in 5-Bromo-2'-deoxy-uridine Labeling and Detection Kit II (Roche). Paraffinembedded sections of $5 \mu \mathrm{m}$ were cut throughout each slice and 5 sections chosen according to systematic random sampling scheme from each slice were processed with 5-Bromo-2'-deoxy-uridine Labeling and Detection Kit II according to the manufacturers protocol for paraffin-embedded tissues. Labeled granule cells of dentate gyrus from 4 individual arbitrary unit areas chosen according to systematic random sampling scheme from each section were counted. A consecutive section of each labeled section was stained with hematoxylin and eosin for the maintenance of orientation.

\section{Assessment of total granule cell number on the basis of optical fractionator}

Frozen brains were cut in the horizontal plane with a thickness of $150 \mu \mathrm{m}$ at $-15^{\circ} \mathrm{C}$ in a cryostat (Leica CM3050, Bensheim, Germany). Sections collected via systematic random sampling scheme were stained with hematoxylen and eosin. The first section in the series to be analyzed was chosen randomly from the first $2 \mathrm{sec}-$ tions. This section and every 2 nd section thereafter were stained for use in the analysis. Thus, the section-sampling fraction (ssf) is $1 / 2$. In each section, granule cells were counted with the optical dissector at regularly predetermined $\mathrm{x}$ and $\mathrm{y}$ axes within the dentate gyrus. Steps " $\mathrm{x}$ " and "y" were predetermined as $200 \mu \mathrm{m}$ each. Microscopic images obtained from granule cell layer in dentate gyrus using X100 oil objective $($ N.A. $=1.25)$ with a microscope (Nicon Eclipe E 600, Tokyo) were transferred to a monitor (Sony Trinitron Color Video Monitor PVM-14N1MDE, Weybridge, UK) using a video camera (Hitachi OSP Color Video Camera VKC22OE, Tokyo). An unbiased counting frame (Gundersen's unbiased counting frame) (West et al. 1991) was then super-imposed on the monitor image of the section. The area of the counting frame of the dissector, a (frame), was known $\left(20 \mu \mathrm{m} \times 20 \mu \mathrm{m}=400 \mu \mathrm{m}^{2}\right)$ relative to the area associated with each $\mathrm{x}, \mathrm{y}$ movement, $\mathrm{a}(\mathrm{x}, \mathrm{y}$ step). Thus, the areal sampling fraction is (asf) $=$ a (frame) / a (x, y step).
At each step of the sampled granule cell layer where the cell nuclei were observed under the frame, the plane of focus was moved $10 \mu \mathrm{m}$ from the surface into the section. The counting frame was then focused through 30 $\mu \mathrm{m}$ of the thickness of the section and the number of cell nuclei was counted with unbiased counting rules $\left(\mathrm{Q}^{-}\right)$. With the optical dissector, it is only necessary to determine the first recognizable profile of the nucleus to come into focus within the counting frame. The height of the dissector was $30 \mu \mathrm{m}$ for this study $(\mathrm{h}=30 \mu \mathrm{m})$.

The mean thickness of each section was calculated. The fraction of the sampled section thickness is referred to as the thickness sampling fraction (tsf) $=\mathrm{h}$ (the height of the dissector) / $\mathrm{t}$ (the mean thickness of the section).

Granule cells were directly counted in a known fraction of granule cell layer of the dentate gyrus. The number of granule cells in the dentate gyrus $(\mathrm{N})$ was estimated as;

$$
\mathrm{N}=\mathrm{Q}^{-} \times(1 / \mathrm{ssf}) \times(1 / \mathrm{asf}) \times(1 / \text { tsf })
$$

$\mathrm{Q}$ : The total number of granule cells counted in the dissectors on the sampled sections.

ssf : The section sampling fraction or the fraction of the sections sampled.

asf : The areal sampling fraction is then a (frame) / a (x, y step).

tsf : The section thickness sampling fraction is then $\mathrm{h} / \mathrm{t}$.

$\mathrm{h}$ : The height of the dissector $(30 \mu \mathrm{m})$.

$\mathrm{t}$ : The mean thickness of the sections.

\section{Statistical analyses}

Statistical analyses for cell counts were performed using the non-parametric Mann Whitney's U-test and $p<$ 0.05 was taken as statistically significant.

\section{Results}

The mean number of granule cells undergoing apoptosis per analyzed arbitrary unit area was significantly increased in the treated group (11.4 \pm 0.73 , mean \pm S.E.M; Figs. 1 and 2 F) when compared to that in the control group $(6.2 \pm 0.6$, mean \pm S.E.M; $p<0.0001$; Figs. 1 and 2D).

On the other hand, the mean number of granule cells undergoing cell proliferation per analyzed arbitrary unit area was also significantly increased in the treated group $(2.38 \pm 0.24$, mean \pm S.E.M; Figs. 1 and $3 \mathrm{~F}$ ) when compared to that in the control group $(1.61 \pm 0.14$, mean \pm S.E.M; $p<0.006$; Figs. 1 and 3D). 

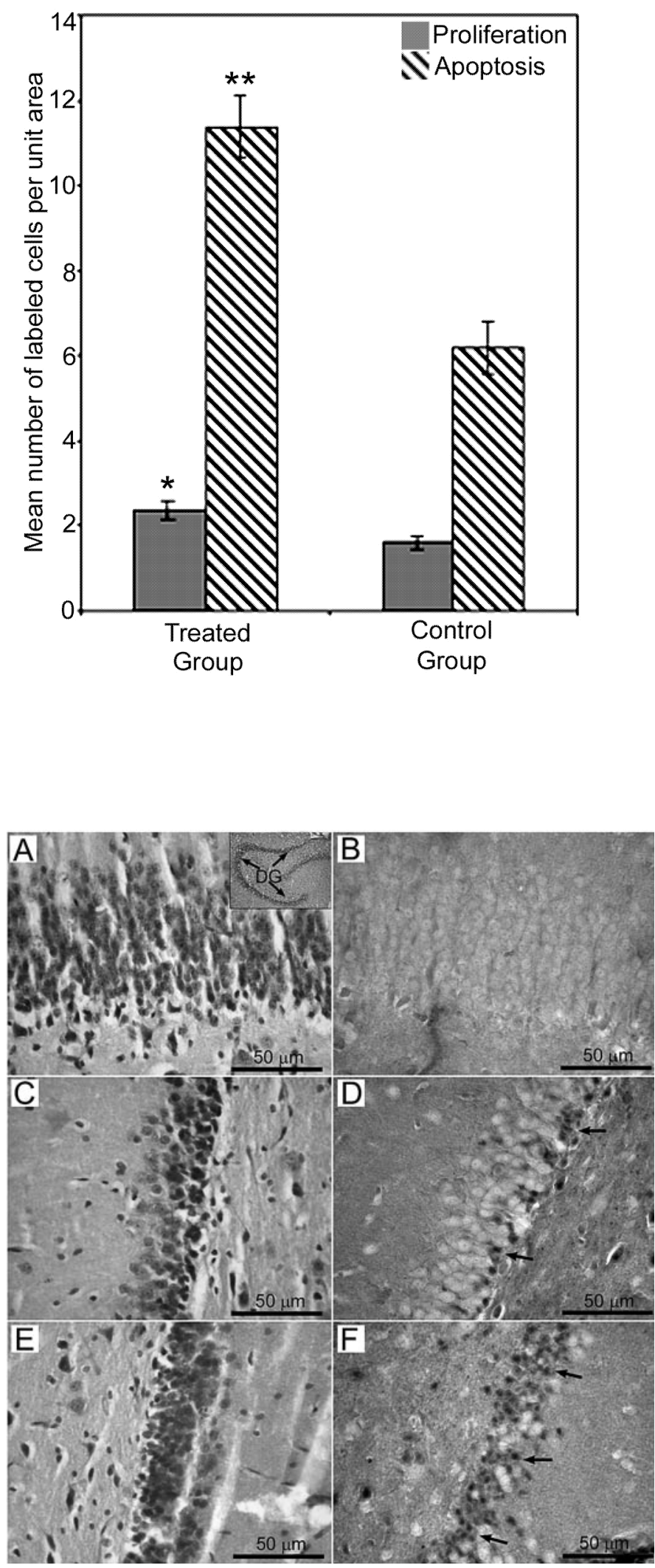

Fig. 1. Analysis of cell proliferation on the basis of BrdU labeling assay revealed a 1.49 fold increase in the treated group when compared to controls $\left({ }^{*} p<0.006\right)$. Analysis of apoptotic cell death on the basis of TUNEL assay, on the other hand, revealed a 1.84 fold increase in the treated group in comparison to controls $\left(^{* *} p<\right.$ 0.0001).

Fig. 2. Representative images for the analysis of apoptotic cell death on the basis of TUNEL assay are shown in panels (B, D, and F), where B represents the background staining of a negative control section processed the same way as the other sections except the step of incubation with the appropriate TUNEL labeling mix. Panels D and F, on the other hand, represent images from control and treated groups, respectively. Arrows indicate examples of counted labeled cells in dentate gyrus. A consecutive section of each labeled section was stained with hematoxylin and eosin for the maintenance of orientation as shown in panels (A, C, and E). Images were taken by $\times 20$ objective. Scale bars $=50 \mu \mathrm{m}$. Inset in A, represents the whole image of dentate gyrus (DG, $\times$ 5 objective) stained with hematoxylin and eosin. 


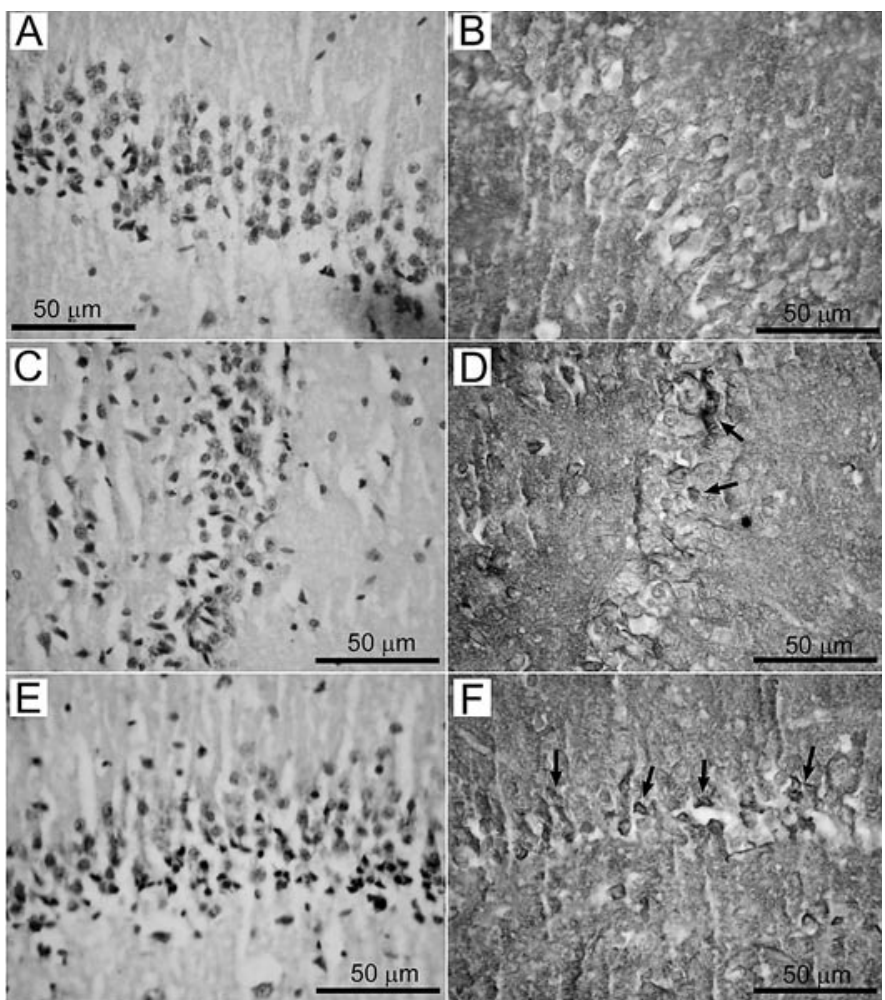

Fig. 3. Representative images for the analysis of cell proliferation on the basis of BrdU labeling are shown in panels (B, D, and F), where B represents the background staining of a negative control section processed the same way as the other sections except the step of incubation with the appropriate Anti-BrdU antibody. Panels $\mathrm{D}$ and $\mathrm{F}$, on the other hand, represent images from control and treated groups, respective1y. Arrows indicate examples of counted labeled cells in dentate gyrus. A consecutive section of each labeled section was stained with hematoxylin and eosin for the maintenance of orientation as shown in panels $(\mathrm{A}, \mathrm{C}$, and E). Images were taken by $\times 20$ objective. Scale bars $=50 \mu \mathrm{m}$.
However, optical fractionator analysis revealed that mean total granule cell number in dentate gyrus was slightly lower in the treated group $(157,053 \pm 4,244$, mean \pm S.E.M $)$ than that in the control group $(164,697 \pm 1,998$, mean \pm S.E.M; Table 1), i.e., the mean total number of granule cells of dentate gyrus in rats fed with $\mathrm{Cu}$ and $\mathrm{EtOH}$ was $4.64 \%$ less then that of control rats, but the difference being statistically not significant $(p>0.05)$.

\section{Discussion}

The objective of this study was to expose the granule cells of the dentate gyrus to a proven potent neurodegenerative treatment, i.e., overdose $\mathrm{Cu}$ and $\mathrm{EtOH}$ co-treatment over a period of 10 days, in order to test the regeneration ability of this gray matter tissue in rats. Results suggested that the apoptotic effect of overdose $\mathrm{Cu}$ and $\mathrm{EtOH}$ co-exposure on granule cells of dentate gyrus is counterbalanced by the co-induced cellular proliferation, thereby maintaining the total granule cell number unaltered.
We have previously shown that overdose $\mathrm{Cu}$ and $\mathrm{EtOH}$ exposure results in severe hippocampal neuronal loss (23\%) in rats (Turgut et al. 2003). However, this study revealed that the same effect was not true for the granule cell number of the dentate gyrus (Table 1). A previous study by Lukoyanov et al. (1999) also showed that the hippocampus CA1 and CA3 subfields had $18 \%$ and $19 \%$ neuronal loss, respectively, due to EtOH exposure, whereas total granule cell number of dentate gyrus did not differ statistically from the control group.

To explain these results the following two hypotheses were suggested. Dentate gyrus is known as the most resistant region to excitotoxic changes among all the hippocampal subfields (Pawlak et al. 2002). It has previously been shown that especially in epileptic changes dentate gyrus is more resistant to damage than does CA1 and CA3 subfields (Meldrum and Bruton 1992; Proper et al. 2001). Supporting this hypothesis are the previous studies showing that in a rat experimental epilepsy model, hippocampus CA1, 
TABLE 1. Total number of granule cells in the left dentate gyrus of treated and control groups

\begin{tabular}{|c|c|c|c|c|c|c|}
\hline Groups & $\begin{array}{c}\text { Animal } \\
\text { No. }\end{array}$ & $\begin{array}{l}\quad \mathrm{Q}^{-} \\
\text {(The total } \\
\text { number of } \\
\text { granule cells } \\
\text { counted) }\end{array}$ & $\begin{array}{l}\qquad 1 / \text { tsf } \\
\text { (The section } \\
\text { thickness } \\
\text { sampling } \\
\text { fraction) }\end{array}$ & \begin{tabular}{l}
\multicolumn{1}{c}{$\mathrm{t}$} \\
(The mean \\
thickness of the \\
section) $(\mu \mathrm{m})$
\end{tabular} & $\begin{array}{l}\quad \mathrm{N} \\
\text { (The total } \\
\text { number of } \\
\text { granule cells) }\end{array}$ & $\begin{array}{c}\mathrm{N} \\
(\text { Mean } \pm \\
\text { S.E.M) }\end{array}$ \\
\hline Treated & 1 & 374 & 2.08 & 62.40 & 155,584 & $157,053 \pm$ \\
\hline \multirow[t]{5}{*}{ Group } & 2 & 379 & 2.25 & 67.40 & 170,550 & 4,244 \\
\hline & 3 & 349 & 2.34 & 70.10 & 163,332 & \\
\hline & 4 & 332 & 2.12 & 63.76 & 140,768 & \\
\hline & 5 & 358 & 2.11 & 63.32 & 151,076 & \\
\hline & 6 & 361 & 2.23 & 67.00 & 161,006 & \\
\hline \multirow[t]{6}{*}{ Control group } & 1 & 345 & 2.35 & 70.60 & 162,150 & $164,697 \pm$ \\
\hline & 2 & 332 & 2.38 & 71.40 & 158,032 & 1,998 \\
\hline & 3 & 386 & 2.23 & 67.00 & 172,156 & \\
\hline & 4 & 355 & 2.31 & 69.50 & 164,010 & \\
\hline & 5 & 391 & 2.15 & 64.50 & 168,130 & \\
\hline & 6 & 359 & 2.28 & 68.60 & 163,704 & \\
\hline
\end{tabular}

* Difference between two groups is not statistically significant $(p>0.05)$. The formula and all the parameters used for estimation of total granule cell number are given in the text in detail.

CA2 and CA3 subfields had significant neuronal loss (Akdogan et al. 2002), whereas dentate gyrus granule cells did not reveal a significant decrease compared to control group (Adiguzel et al. 2002). Alternatively, increased cell proliferation at subgranuler zone of dentate gyrus may contribute to the granule cell number in dentate gyrus (Eriksson et al. 1998). Neurogenesis is present in brain tissue during the prenatal period (Pawlak et al. 2002). Studies also showed that neurogenesis of granule cells in dentate gyrus continue during the postnatal and adult life (Bayer et al. 1982; Eriksson et al. 1998; Gage et al. 1998; Pawlak et al. 2002; Zharkovsky et al. 2003). Especially cells from subgranular zone migrate to the granule cell layer and differentiate into granule cells (Eriksson et al. 1998). It has also been shown that administration of kainic acid (Gray and Sundstrom 1998), ischemia (Kee et al. 2001), electroconvulsive shock (Scott et al. 2000) and pilocarpine-induced status epilepticus (Covolan et al. 2000) induce neurogenesis in rat dentate gyrus. Cadete-Leite et al. (1988) have shown that chron- ic alcohol consumption may induce granule cell loss accompanied by dentritic regrowth in dentate gyrus. Pawlak et al. (2002), on the other hand, have shown induced cell proliferation by $\mathrm{EtOH}$ due to blockage of NMDA receptors in mice dentate gyrus. In our case, the neurotoxic effects of $\mathrm{Cu}$ and $\mathrm{EtOH}$ may be counterbalanced with induced cell proliferation also supported by other recent studies (Cadete- Leite et al. 1988; Pawlak et al. 2002; Zharkovsky et al. 2003). Thus, total neuron number may not show a significant decrease due to $\mathrm{Cu}$ and $\mathrm{EtOH}$ co-exposure. This notion has been further investigated via analyses of cell death, i.e., by TUNEL method, and of cell proliferation, i.e., by BrdU labeling and staining of proliferating granule cells of dentate gyrus. Indeed, results revealed that the rate of apoptosis was increased by 1.84 folds in the treated group ( $p$ $<0.0001$ ) in parallel to the 1.49 fold increase of cell proliferation $(p<0.006)$ when compared to those in control group (Figs. 1, 2 and 3), maintaining the total granule cell number statistically unaltered. 
In conclusion, what makes dentate gyrus more resistant to proven excitotoxic and neurodegenerative changes among all the hippocampal subfields (as suggested in our first hypothesis) is actually its ability to regenerate its granule cells by cellular proliferation (as suggested in our second hypothesis). The finding that cell death can be counterbalanced by increased cell proliferation in the dentate gyrus is also of potential clinical importance; it should be investigated if the newly born neurons in this area participate functionally in the learning, memory and other relevant functions of dentate gyrus. Finally, these results represent one more example of plasticity and reparative capacity of the rat dentate gyrus.

\section{Acknowledgements}

Authors thank to Prof. Dr. Suleyman Kaplan (Department of Histology and Embryology, School of Medicine, Ondokuz Mayis University, Turkey) for his guidance in stereological methods; Prof. Dr. Ender Duzcan (Department of Pathology, School of Medicine, Pamukkale University, Turkey), Asiye Usta and Arzu Armagan Yay (Department of Histology and Embryology, School of Medicine, Pamukkale University, Turkey) for their technical support.

\section{References}

Adiguzel, E., Akdogan, I., Duzcan, S.E. \& Tufan, A.C. (2002) Effect of penicillin induced epilepsy seizure on granulare cell layer of dentate gyrus in rat: A stereological study. Neurosci. Res. Commun., 31, 101-109.

Akdogan, I., Unal, N. \& Adiguzel, E. (2002) Estimation of the number of neurons in the hippocampus of rats with penicillin induced epilepsy. Image Anal. Stereol., 21, 117-120.

Amaral, D.G. \& Witter, M.P. (1989) The three-dimensional organization of the hippocampal formation: A review of anatomical data. Neuroscience, 31, 571-591.

Arendt, T., Hennig, D., Gray, J.A. \& Marchbanks, R. (1988) Loss of neurons in the rat basal forebrain cholinergic projection system after prolonged intake of alcohol. Brain Res. Bull., 21, 563-570.

Armstrong, C., Leong, W. \& Lees, G.J. (2001) Comparative effects of metal chelating agents on the neuronal cytotoxicity induced by copper $\left(\mathrm{Cu}^{+2}\right)$, iron $\left(\mathrm{Fe}^{+3}\right)$, and zinc in the hippocampus. Brain Res., 892, 51-62.
Barranguet, C., Plans, M., Grinten, E., Sinke, J.J. \& Admiraal, W. (2002) Development of photosynthetic biofilms affected by dissolved and sorbed copper in a eutrophic river. Environ. Toxicol. Chem., 21, 1955-1965.

Bayer, S.A., Yackel, J.W. \& Puri, P.S. (1982) Neurons in the rat dentate gyrus granular layer substantially increase during juvenile and adult life. Science, 216, 890-892.

Bengochea, O. \& Gonzalo, L.M. (1990) Effect of chronic alcoholism on the human hippocampus. Histol. Histopathol., 5, 349-357.

Berry, M., Bannister, L.H. \& Standring, S.M. (1995) In: Gray's Anatomy 38th edition, edited by P.L. Williams. Churchill Livingstone, New York, pp. 901-1399.

Cadete-Leite, A., Alves, M.C., Tavares, M.A. \& PaulaBarbosa, M.M. (1990) Effects of choronic alcohol intake and withdrawal on the prefrontal neurons and synapses. Alcohol, 7, 145-152.

Cadete-Leite, A., Tavares, M.A., Uylings, H.B.M. \& Paula-Barbosa, M. (1988) Granule cell loss and dendritic regrowth in the hippocampal dentate gyrus of the rat after chronic alcohol consumption. Brain Res., 473, 1-14.

Charness, M.E. (1993) Brain lesions in alcoholics. Alcohol. Clin. Exp. Res., 17, 2-11.

Chen, W.J., Berryhill, E.C. \& West, J.R. (2001) Zinc supplementation does not attenuate alcohol-induced cerebellar Purkinje cell loss during the brain growth spurt period. Alcohol. Clin. Exp. Res., 25, 600-605.

Covolan, L., Ribeiro, L.T., Longo, B.M. \& Mello, L.E. (2000) Cell damage and neurogenesis in the dentate granule cell layer of adult rats after pilocarpine- or kainate-induced status epilepticus. Hippocampus, 10, 169-180.

Eriksson, P.S., Perfilieva, E., Bjork-Erikson, T., Alborn, A.M., Nordborg, C., Peterson, D.A. \& Gage, F.H. (1998) Neurogenesis in adult human hippocampus. Nat. Med., 4, 1313-1317.

Gage, F.H., Kempermann, G., Palmer, T.D., Peterson, D.A. \& Ray, J. (1998) Multipotent progenitor cells in the adult dentate gyrus. J. Neurobiol., 36, 249-266.

Gray, W.P. \& Sundstrom, L.E. (1998) Kainic acid increases the proliferation of granule cell progenitors in the dentate gyrus of the adult rat. Brain Res., 790, 52-59.

Horning, M.S., Blakemore, L.J. \& Trombley, P.Q. (2000) Endogeneous mechanisms of neuroprotection: role of zinc, copper, and carnosine. Brain Res., 852, 56-61.

Kee, N.J., Preston, E. \& Wojtowicz, J.M. (2001) Enhanced neurogenesis after transient global isch- 
emia in the dentate gyrus of the rat. Exp. Brain Res., 136, 313-320.

Lukoyanov, N.V., Brandao, F., Cadete-Leite, A., Maderia, M.D. \& Paula-Barbosa, M.M. (2000) Synaptic reorganization in the hippocampal formation of alcohol-fed rats may compensate for functional deficits related to neuronal loss. Alcohol, 20, 139-148.

Lukoyanov, N.V., Maderia, M.D. \& Paula-Barbosa, M.M. (1999) Behavioral and neuroanatomical consequences of choronic ethanol intake and witdrawal. Physiol. Behav., 66, 337-346.

Meldrum, B.S. \& Bruton, C.J. (1992) In: Greenfield's Neuropathology edited by J.B. Geenfield, J.H. Adams \& L.W. Duchen. Oxford University Press, pp. 1246-1279.

Obernier, J.A., White, A.M., Swartzwelder, H.S. \& Crews, F.T. (2002) Cognitive deficits and CNS damage after a 4-day binge ethanol exposure in rats. Pharmacol. Biochem. Behav., 72, 521-532.

Paula-Barbosa, M.M., Brandao, F., Andrade, J.P., Maderia, M.D., Zimmer, J. \& Cadete-Leite, A. (1991) Intracerebral grafting impedes hippocampal cell loss during withdrawal after longterm alcohol consumption in rats. Alcohol Alcoholism, 26, 177-190.

Paula-Barbosa, M.M., Brandao, F., Maderia, M.D. \& Cadete-Leite, A. (1993) Structural changes in the hippocampal formation after long-term alcohol consumption and withdrawal in the rat. Addiction, 88, 237-247.

Pawlak, R., Skrzypiec, A., Sulkowski, S. \& Buczko, W. (2002) Ethanol-induced neurotoxicity is counterbalanced by increased cell proliferation in mouse dentate gyrus. Neurosci. Lett., 327,
83-86.

Proper, E.A., Hoogland, G., Van Veelen, C.W.M. \& Grann, P.N.E. (2001) Morphological changes in the human epileptogenic hippocampus. Neurosci. Res. Commun., 29, 129-146.

Sarkar, B. (2000) Copper transport and its defect in Wilson disease: characterization of the copperbinding domain of Wilson disease ATPase. $J$. Inorg. Biochem., 79, 187-191.

Scott, B.W., Wojtowicz, J.M. \& Burnham, W.M. (2000) Neurogenesis in the dentate gyrus of the rat following electroconvulsive shock seizures. Exp. Neurol., 165, 231-236.

Shallari, S., Schwartz, C., Hasko, A. \& Morel, J.L. (1998) Heavy metals in soils and plants of serpentine and industrial sites of Albania. Sci. Total Environ., 209, 133-142.

Turgut, G., Akdogan, I., Adiguzel, E. \& Genc, O. (2003) Effect of copper overload with ethanol uptake on hippocampal neurons. Tohoku J. Exp. Med., 199, 239-245.

Waggoner, D.J., Bartnikas, T.B. \& Gitlin, J.D. (1999) The role of copper in neurodegenerative disease. Neurobiol. Dis., 6, 221-230.

West, M.J., Slomianka, L. \& Gundersen, H.J.G. (1991) Unbiased stereological estimation of the total number of neurons in the subdivisions of the rat hippocampus using the optical fractionator. Anat. Rec., 231, 482-487.

Zharkovsky, T., Kaasik, A., Jaako, K. \& Zharkovsky, A. (2003) Neurodegeneration and production of the new cells in the dentate gyrus of juvenile rat hippocampus after a single administration of ethanol. Brain Res., 978, 115-123. 